\title{
Cooperation of Nicotinamide with Mesenchymal Stem Cells to Control Diabetes Mellitus-Induced by Streptozotocin in Rats
}

\author{
Eman, G. Mohamad', Hanaa, M. Abdel-Fattah ${ }^{1}$, Nora, M. El-Sheikh ${ }^{1}$ and \\ Mervat S. El-Ansary ${ }^{2}$
}

1 Biochemistry and Nutrition Department, Faculty of Women for Arts, Science and Education, Ain Shams University, Cairo, Egypt

2 Pathology Department, Faculty of Medicine, Cairo University

\begin{abstract}
:
The main objective of this work is to assess the role of nicotinamide in protecting $\beta$-cells of rat's pancreas after STZ injection and to study the therapeutic potency of bone marrow mesenchymal stem cells in STZ-induced diabetic rats. Ten male albino rats were sacrificed and used for isolation and differentiation of MSCs into insulin producing cells within 4 weeks. Fifty male albino rats were divided into 5 groups. Group (1): normal control. The other groups were injected with STZ $50 \mathrm{mg} / \mathrm{kg} \mathrm{b.w}$. for induction of diabetes. Group (2): diabetic control, group (3): diabetic rats received oral nicotinamide (NIC) $100 \mathrm{mg} / \mathrm{kg}$ b.w. daily (NIC group), group (4): diabetic rats injected subcutaneously with differentiated MSCs $5 \times 10^{6}$ cells per rat (MSCs group), group (5): diabetic rats injected subcutaneously with differentiated MSCs $5 \times 10^{6}$ cells per rat and received oral NIC $100 \mathrm{mg} / \mathrm{kg}$ b.w. daily (MSCs + NIC group) the treatment continued for 4 weeks. The results indicated that injection with MSCs and administration of oral NIC ameliorate the glucose homeostasis by decreasing blood glucose and increasing insulin and C-peptide levels, improving antioxidant status by decreasing serum MDA level and increasing the activity of (serum TOC, liver SOD and GPX), serum lipid profile TC, TAGs, LDL-C and VLDL-C were deceased while HDL-C was increased while using both of MSCs and NIC caused more improvement which was evidenced in the histopathological examination of pancreatic cells. In conclusion: treatment with nicotinamide improves the diabetic state of rats as nicotinamide is believed to have anti-hyperglycemic and anti-oxidant properties. MSCs were successfully differentiated into numerous numbers of $\beta$-cells and injection with $5 \times 10^{6}$ MSCs clearly support pancreas tissue repair.
\end{abstract}

Key words: mesenchymal stem cells, streptozotocin-induced diabetes, nicotinamide, antioxidant status and lipid profile.

Corresponding auther: Prof. Dr. Nora Mohamed Afifi El-Sheikh

E.mail: elsheikh_nora@yahoo.com Tel: 01000353845 


\section{Introduction}

Diabetes mellitus (DM) is a metabolic disorder characterized by the presence of hyperglycemia due to defective insulin secretion, insulin action or both of them. The chronic hyperglycemia of diabetes is associated with relatively specific long term micro-vascular complications affecting the eyes, kidneys and nerves as well as increased risk of cardiovascular disease (CVD) (Goldenberg and Punthakee, 2013).

Diabetes is caused by either insulin deficiency due to the destruction of insulin secreting pancreatic cells (type-1 DM) or by a relative insulin deficiency due to decreased insulin sensitivity (type-2 DM). People with type 1 diabetes must take insulin several times a day, diabetes researchers have been searching for ways to replace the insulin-producing cells of the pancreas that are destroyed by a patient's own immune system. Islet transplantation has been shown to restore normoglycemia in type $1 \mathrm{DM}$ but a limited supply of human islet tissues prevents this therapy from being used (Shapiro et al., 2000).

Experimental induction of diabetes mellitus in animal models is essential for the advancement of our knowledge and understanding of the various aspects of its pathogenesis and ultimately finding new therapies and cure. Streptozotocin (STZ) has been extensively used to induce diabetes for various studies in laboratory animals. STZ is a naturally occurring chemical that is toxic to pancreatic $\beta$-cells in mammals and can produce an animal model of type 1 DM (Krishna et al., 2012 and Tsai et al., 2012).

Stem cells are cells found in all multi-cellular organisms. They are characterized by the ability to renew themselves through mitotic cell division and differentiating into a diverse range of specialized cell types. The two broad types of mammalian stem cells are: Embryonic stem cells (ESC) that are isolated from the inner cell mass of blastocysts and adult stem cells that are found in adult tissues (Ramiya et al., 2000).

Mesenchymal stem cells (MSCs) were first isolated from bone marrow and have the potential to differentiate in culture into muscle cells, adipocytes, osteocytes, chondrocytes, cardiomyocytes and pancreatic $\beta$-cells. Moreover, following systemic injection, MSCs have been shown to be incorporated into a variety of tissues including bone, muscle, lung and insulin producing cells but the number of MSCs that can be cost-effectively isolated and differentiated remains a major limitation (Tsai et al., 2012).

Nicotinamide is the amide form of vitamin $\mathrm{B}_{3}$ and is obtained through synthesis in the body or as a dietary source and supplement (Hara et al., 2007). Nicotinamide is a safe, naturally occurring substance which appears to be non-toxic to humans that has been shown to be neuroprotective, immunomedulator and anti-inflammatory agent. Nicotinamide has an ability to slow down the rate of free radicals formation probably through direct interaction with lipid hydroperoxides (Kuchmerovska et al., 2008).

Nicotinamide has been shown to protect pancreatic islets from inflammation and stimulate endocrine differentiation of rat $\beta$-cells in vivo (Banerjee et al., 2005). The 
beneficial action of nicotinamide on diabetes-associated failures in various organs can also be related to normalization of cellular function most likely due to its antioxidant properties (Kuchmerovska et al., 2004).

The aim of the present investigation is to study the role of nicotinamide in protecting $\beta$-cells in STZ-induced diabetic rats and minimizing the complication of diabetes. Also to study the therapeutic potency of bone marrow mesenchymal stem cells in diabetic rats.

\section{Material and Methods}

\subsection{Materials :}

Streptozotocin, Nicotinamide and chemicals for stem cells culture: Roswell Park Memorial Institute (RPMI) medium, Low glucose Dulbecco's Modified Eagle's medium (L-DMEM), High glucose Dulbecco's Modified Eagle's medium (H-DMEM), $\beta$-mercaptoethanol, Fetal Calf Serum (FCS), Trypsin, Xendine and Phosphate Buffer Saline (PBS) were purchased from Sigma Chemical Co., St. Louis, USA. Basal diet was prepared according to American Institute of Nutrition AIN-93G adjusted by Reeves et al. (1993). Sixty adult male Albino Wister rats weighing between 150-180 g were used in this study, they were purchased from the animal house of Faculty of Medicine, Cairo University.

\subsection{Methods:}

\subsubsection{Isolation and culture of bone marrow mesenchymal stem cells:}

Ten male albino rats were sacrificed, femurs and tibiae of rats were separated and adherent soft tissues and muscle of the knee end were carefully removed. Bone marrow cells were flushed from the medullary cavities of femurs and tibiae and disaggregated into a single-cell suspension by sequential passage through a needle. Cells were cultured in low glucose $(4.5 \mathrm{mmol} / \mathrm{L}$ glucose $)$ L-DMEM including $10 \mathrm{mmol} / \mathrm{L}$ nicotinamide $+1 \mathrm{mmol} / \mathrm{L} \beta$-mercaptoetha-nol + FCS and mononuclear cells dispersed into single cell suspension in a density of $1 \times 10^{9} / \mathrm{L}$ at $37^{\circ} \mathrm{C}, 50 \mathrm{~mL} / \mathrm{L} \mathrm{CO}_{2}$ incubator for $48 \mathrm{hr}$. (Chen et al., 2004). In the third day suspended cells were removed and adherent cells cultured by changing the medium every third or fourth day thereafter, after 12 days in culture, adherent cells were washed with $0.25 \%$ trypsin for $5 \mathrm{~min}$. at $37^{\circ} \mathrm{C}$ rinsed with fetal calf serum and recultured in fresh high glucose $(23 \mathrm{mmol} / \mathrm{L}$ glucose $)$ H-DMEM including $10 \mathrm{mmol} / \mathrm{L}$ niocotinamide $+1 \mathrm{mmol} / \mathrm{L} \beta$-mercaptoethanol + xendine (Dong et al., 2008). After 12 days in culture MSC were injected subcutaneously at a dose of $5 \times 10^{6}$ cells per rat after suspension in PBS (Abdel Aziz et al., 2008).

2.2.2. Induction of diabetes: Diabetes was induced in 40 rats, and they were received oral nicotinamide dissolved in distilled water at a dose of $1 \mathrm{~g} / \mathrm{kg} \mathrm{b}$.w. given daily for 3 consecutive days to prevent complete destruction of $\beta$-cells (Alenzi, 2009). A single interperitonial injection of streptozotocin (STZ) $50 \mathrm{mg} / \mathrm{kg} \mathrm{b.w.} \mathrm{which} \mathrm{solubilized} \mathrm{in} 0.1$ M sodium citrate buffer ( $\mathrm{pH} 4.5$ ) was used for induction of diabetes mellitus (Raja et al., 2010). 
2.2.3. Experimental design: Rats were divided into five groups each of ten rats in each; the animals were housed individually in metallic cages and they were fed basal diet for 7 days as acclimatization period. All rats received water and diet ad libitum and subjected to experimentation for four weeks.

Group (1): Rats fed on basal diet (Normal control).

The other groups made diabetic and fed on basal diet.

Group (2): (Diabetic control).

Group (3): Diabetic rats received oral nicotinamide (NIC) $100 \mathrm{mg} / \mathrm{kg}$ body weight daily (Ibrahim and Rizk, 2008) (NIC group).

Group (4): Diabetic rats injected subcutaneously with differentiated MSCs $5 \times 10^{6}$ cells per rat (MSCs group).

Group (5): Diabetic rats injected subcutaneously with differentiated MSCs $5 \times 10^{6}$ cells per rat and received oral nicotinamide $100 \mathrm{mg} / \mathrm{kg}$ body weight daily (MSCs + NIC group).

During the experimental period food intake was recorded each week and the animals were weighed weekly to monitor the body weight change and to calculate feed efficiency ratio according to Guo et al. (2002). Blood glucose level was determined with Haemo glucose test strips (Boehringer Mannheim, Germany) after 3 days from STZ injection (initial) and at the end of the experiment (final).

\subsubsection{Handling of blood and tissues samples:}

At the end of the experimental period and after overnight fasting blood samples were collected from the retro-orbital vein using sterilized capillary tubes. Serum was obtained by centrifugation of blood at $3000 \mathrm{rpm}$ for 15 minutes and used for the determination of insulin and C-Peptide levels according to the radioimmunoassay (RIA) method described by Thorell and Lanner (1973) and Finlay and Dillard (2007) respectively, determination of malondialdehyde (MDA) and total oxidative capacity (TOC) according to Botsoglou et al. (1994) and Flohe and Gunzler (1984), respectively. lipid profile including total cholesterol (TC), triacylglycerols (TAGs), high density lipoprotein-cholesterol (HDL-C), were determined by enzymatic colorimetric methods according to Allain et al. (1974), Fossati et al. (1982), and Friedewald et al. (1972), respectively ,low density lipoprotein-cholesterol (LDL-C) and very low density lipoprotein-cholesterol (VLDL-C) were calculated according to Friedewald et al. (1972).

Liver tissues were homogenized in cold phosphate buffer saline and then centrifuged for $10 \mathrm{~min}$ at $14.000 \mathrm{rpm}$. The clear supernatant was used for the determination of glutathione peroxidase (GPX) and superoxide dismutase (SOD) activity according to Ursini et al. (1985) and Oyanagi (1984), respectively.

Pancreatic samples were collected for histopathological examination and preserved in $10 \%$ buffered formalin solution (pH 7.4). Haematoxylin and Eosin ( $\mathrm{H} \mathrm{\&} \mathrm{E)} \mathrm{stain} \mathrm{was}$ used for microscopic examination with power magnification 400 (Bancroft and Gample, 2008). 


\subsection{Statistical analysis:}

SPSS windows version (9) was used for the analysis of data. One way analysis of variance (ANOVA) was used for comparison of quantitative variable with each other according to Steel and Torrie (1980). Description of presentative variable in the form mean $\pm \mathrm{SE}$ was done. Differences were considered significant if $\mathrm{P} \leq 0.05$.

\section{Results and discussion:}

\subsection{Initial \& final blood glucose levels, serum insulin and C-peptide assay:}

In the current study we observed that, STZ injection caused severe hyperglycemia in all diabetic groups compared to normal control group and this appear in initial blood glucose level. Elevation of blood glucose levels started 3 days after STZ injection and continued until the end of the experiment.

It appeared from the results in table (1) that final blood glucose level in diabetic group showed continuous elevation which confirms a diabetic state with decrease in insulin and C-peptide levels, also confirmed by damage of pancreatic cells as shown in histological examination.

Table (1): Fasting initial and final blood glucose levels, serum insulin and C-peptide level in diabetic rats treated with nicotinamide, mesenchymal stem cells or combination of them (mean $\pm \mathbf{S E}$ ), $\mathrm{n}=10$ rats.

\begin{tabular}{|c|c|c|c|c|}
\hline Groups $\quad$ Parameters & $\begin{array}{l}\text { Initial glucose } \\
\quad(\mathbf{m g} / \mathbf{d l})\end{array}$ & $\begin{array}{l}\text { Final glucose } \\
\quad(\mathrm{mg} / \mathrm{dl})\end{array}$ & Insulin (ng/dl) & $\begin{array}{l}\text { C-peptide level } \\
\text { (PM) }\end{array}$ \\
\hline Normal control & $107.4 \pm 3.72^{b}$ & $102.4 \pm 4.92^{\mathrm{d}}$ & $1.14 \pm 0.04^{\mathrm{a}}$ & $10.46 \pm 0.16^{\mathrm{a}}$ \\
\hline Diabetic & $335.3 \pm 42.29^{\mathrm{a}}$ & $377.9 \pm 40.31^{\mathrm{a}}$ & $0.40 \pm 0.03^{\mathrm{d}}$ & $4.08 \pm 0.06^{\mathrm{e}}$ \\
\hline$\%$ change & 212 & 269 & -64.91 & -61 \\
\hline $\begin{array}{l}\text { Diabetic + NIC } \\
\% \text { change } \\
\% \text { change* }\end{array}$ & $\begin{array}{c}322.9 \pm 26.52^{a} \\
200.65 \\
-3.7\end{array}$ & $\begin{array}{c}268.7 \pm 11.93^{b} \\
162.4 \\
-28.9 \\
\end{array}$ & $\begin{array}{c}0.63 \pm 0.03^{\mathrm{c}} \\
-44.74 \\
57.5\end{array}$ & $\begin{array}{c}6.56 \pm 0.07^{\mathrm{d}} \\
-37.28 \\
60.78 \\
\end{array}$ \\
\hline Diabetic + MSCs & $352.8 \pm 34.07^{\mathrm{a}}$ & $219.7 \pm 10.87^{\text {bc }}$ & $0.70 \pm 0.04^{\mathrm{c}}$ & $7.98 \pm 0.08^{\mathrm{c}}$ \\
\hline$\%$ change & 228.49 & 113.87 & -38.6 & -23.71 \\
\hline$\%$ change* & 5.2 & -42.05 & 75 & 95.6 \\
\hline Diabetic + MSCs + NIC & $309.9 \pm 35.74^{\mathbf{b}}$ & $197.0 \pm 9.21^{\mathbf{c}}$ & $0.97 \pm 0.04^{\mathbf{b}}$ & $9.91 \pm 0.08^{\mathbf{b}}$ \\
\hline$\%$ change & 188.55 & 92.38 & -14.91 & -5.26 \\
\hline$\%$ change* & 7.5 & -47.87 & 142.5 & 142.9 \\
\hline LSD & 89.6 & 56.9 & 0.09 & 0.28 \\
\hline
\end{tabular}

$\mathrm{P} \leq 0.05$ there are no significant difference between means have the same letters in the same column.

$\%$ change: percentage change from normal control. \% change*: percentage change from diabetic.

In agreement with our results, STZ (55 mg/kg b.w.) selectively destroys $\beta$-cells of pancreas that secrete insulin, which causes less active pancreatic cells and produces diabetes mellitus. There should be many surviving $\beta$-cells even after treatment with a low dose of STZ and regeneration is also possible (Mohan et al., 2013). 
The major finding of this study are showed that all diabetic groups treated with NIC and MSCs have significant decrease $(\mathrm{P} \leq 0.05)$ in final blood glucose compared to diabetic group, the most significant decrease was seen in G5 (diabetic + MSCs + NIC) (47.87\%) from diabetic group. This was followed by G4 (diabetic + MSCs) (42.05\%) and finally G3 (diabetic + NIC) $(28.90 \%)$. This was associated with an improvement in the appearance of the pancreatic cells as shown in histological examination.

Our results showed that while insulin and C-peptide levels were significantly decreased in diabetic groups $(\mathrm{P} \leq 0.05)$ compared to normal control group, (NIC) and (MSCs) treatment improved glucose homeostasis and caused significant elevation in insulin and C-peptide levels compared to diabetic group. Insulin and C-peptide levels were significantly increased in NIC group $(0.63 \pm 0.03 \mathrm{ng} / \mathrm{dl})$ and $(6.56 \pm 0.07 \mathrm{PM})$, respectively, in MSCs group to be $(0.70 \pm 0.04 \mathrm{ng} / \mathrm{dl})$ and $(7.98 \pm 0.08 \mathrm{PM})$, respectively vs. $(0.40 \pm 0.03 \mathrm{ng} / \mathrm{dl})$ and $(4.08 \pm 0.06 \mathrm{PM})$, respectively in diabetic group and the most significant increase was found when using both of MSCs and NIC (0.97 \pm $0.04 \mathrm{ng} / \mathrm{dl})$ and $(9.91 \pm 0.08 \mathrm{PM})$ respectively.

There should be many surviving $\beta$-cells even after the treatment with STZ and so the regeneration of these cells is possible. The decrease in blood glucose level in diabetic rats treated with NIC may be due to a combination of the following effects: nicotinamide may protect residual $\beta$-cells, promote $\beta$-cell regeneration or improve insulin secretion by increasing intracellular $\mathrm{NAD}^{+}$and reduces the toxicity of free radicals. The possible option to achieve normoglycemia is the renewal of $\beta$-cells. MSCs have the ability to self-renewal and to differentiate into insulin producing cells and this may be the cause of blood glucose stabilization which shown in MSCs injected groups.

These findings are in agreement with that reported by Alenzi (2009) who found that STZ-induced diabetes was manifested as a significant elevation in fasting blood glucose $(146.1 \%)$ and significant reductions in serum insulin (82.2\%) and C-peptide $(90.5 \%)$ levels. When rats treated with NIC ( $1 \mathrm{~g} / \mathrm{kg}$ b.w./day) 3 days prior to STZ injection and for 14 days after STZ injection, fasting blood glucose, serum insulin and C-peptide levels showed significant improvement.

NIC treatment maintains $\beta$-cell function in diabetic patients without increasing maximal insulin secretory capacity (i.e. without increasing $\beta$-cell mass). Administration of NIC increases $\mathrm{NAD}^{+}$content in different tissues. Moreover, NIC increases intracellular $\mathrm{NAD}^{+}$and prevents $\mathrm{NAD}^{+}$depletion under different pathological conditions. This effect is due to reduce the utilization and increase the biosynthesis of $\mathrm{NAD}^{+}$(Surjana et al., 2010).

Culture-expanded MSCs can reverse STZ-induced diabetes in mice and results in the appearance of functional pancreatic insulin-secreting cells and normoglycemia when used $1 \times 10^{5}$ MSCs as single injection through tail vein. After 15 days, blood glucose level and serum insulin concentrations of diabetic animals rapidly returned to normal level, which means that MSCs injection clearly support pancreas tissue repair, stabilization of normal blood glucose and serum insulin levels (Urbán et al., 2008). 
As C-peptide is released from proinsulin and unlike the A- and B- chains of insulin, it is not taken up by the cells. Thus, levels of C-peptide can be used as a marker of insulin secretion. (Wang et al., 2011) showed that after exposure of MSCs to differentiation conditions, immunocytochemical staining revealed that the cells expressed both insulin and C-peptide. The cells were transplanted into diabetic mice and the blood sugar levels tend to decrease with greater expression of C-peptide levels.

In a sample that contains $1.5 \times 10^{4} \mathrm{MSCs}$, transplantation of insulin-producing cells via the portal vein of diabetic rats, C-peptide was found in the transplanted cells of the liver. These findings suggest that the transplanted cells secreted functional insulin on the fourth week after transplantation. Blood glucose levels decreased to approximately $250 \mathrm{mg} / \mathrm{dl}$ in comparison to $530 \mathrm{mg} / \mathrm{dl}$ in STZ controls. The transplantation may also slow down the appearance of symptoms of DM rather than cure the disease (Tsai et al., 2012).

\subsection{Serum MDA and TOC, Liver GPX and SOD:}

It is evident from the results in table (2) that diabetes significantly suppressed the activities of the studied antioxidant enzymes (serum TOC, liver GPX and SOD). The values reached to $0.29 \pm 0.003 \mathrm{mmol} / 1,2.69 \pm 0.02$ ( $\mu \mathrm{mol}$ of GSH / $\mathrm{mg}$ protein) and $4.48 \pm 0.02$ (U/30 $\mathrm{min} / \mathrm{mg}$ protein), respectively compared to normal control levels that are $0.57 \pm 0.003 \mathrm{mmol} / \mathrm{l}, 5.43 \pm 0.03$ ( $\mu \mathrm{mol}$ of $\mathrm{GSH} / \mathrm{mg}$ protein) and $7.74 \pm 0.02$ (U/30 $\mathrm{min} / \mathrm{mg}$ protein), respectively. There was a significant increase $(\mathrm{P} \leq 0.05)$ in serum MDA level $(0.26 \pm 0.003 \mu \mathrm{M} / 100 \mathrm{ml})$ compared to normal control $(0.18 \pm 0.002$ $\mu \mathrm{M} / 100 \mathrm{ml})$.

Table (2): Serum malondialdehyde (MDA) and total oxidative capacity (TOC), liver glutathione peroxidase (GPX) and superoxide dismutase (SOD) in diabetic rats treated with nicotinamide, mesenchymal stem cells or combination of them (mean $\pm \mathbf{S E}), \mathrm{n}=10$ rats

\begin{tabular}{|c|c|c|c|c|}
\hline Groups & $\operatorname{MDA}(\mu \mathrm{M} / 100 \mathrm{ml})$ & TOC (mmol/l) & $\begin{array}{c}\text { GPX } \\
\begin{array}{c}(\mu \mathrm{mol} \text { of GSH } / \mathrm{mg} \\
\text { protein })\end{array} \\
\end{array}$ & $\begin{array}{c}\text { SOD } \\
(\mathrm{U} / 30 \mathrm{~min} / \mathrm{mg} \\
\text { protein) }\end{array}$ \\
\hline Normal control & $0.18 \pm 0.002^{d}$ & $0.57 \pm 0.003^{\mathrm{a}}$ & $5.43 \pm 0.03^{\mathrm{a}}$ & $7.74 \pm 0.02^{\mathrm{a}}$ \\
\hline $\begin{array}{l}\text { Diabetic } \\
\% \text { change }\end{array}$ & $\begin{array}{c}0.26 \pm 0.003^{\mathrm{a}} \\
44.44\end{array}$ & $\begin{array}{c}0.29 \pm 0.003^{\mathrm{e}} \\
-49.12\end{array}$ & $\begin{array}{c}2.69 \pm 0.02^{\mathrm{e}} \\
-50.46\end{array}$ & $\begin{array}{c}4.48 \pm 0.02^{\mathrm{e}} \\
-42.12\end{array}$ \\
\hline $\begin{array}{c}\text { Diabetic }+ \text { NIC } \\
\% \text { change } \\
\% \text { change* }\end{array}$ & $\begin{array}{c}0.23 \pm 0.002^{b} \\
27.78 \\
-11.54\end{array}$ & $\begin{array}{c}0.31 \pm 0.001^{\mathbf{d}} \\
-45.61 \\
6.9\end{array}$ & $\begin{array}{c}3.12 \pm 0.04^{\mathrm{d}} \\
-42.54 \\
16\end{array}$ & $\begin{array}{c}6.01 \pm 0.04^{\mathbf{d}} \\
-22.35 \\
34.15\end{array}$ \\
\hline $\begin{array}{c}\text { Diabetic + MSCs } \\
\% \text { change } \\
\% \text { change } * \\
\end{array}$ & $\begin{array}{c}0.21 \pm 0.002^{\mathrm{c}} \\
16.67 \\
-19.23 \\
\end{array}$ & $\begin{array}{c}0.33 \pm 0.002^{\mathbf{c}} \\
-42.11 \\
13.8 \\
\end{array}$ & $\begin{array}{c}3.74 \pm 0.02^{\mathrm{c}} \\
-31.12 \\
39.03\end{array}$ & $\begin{array}{c}6.27 \pm 0.03^{\mathrm{c}} \\
-19 \\
40 \\
\end{array}$ \\
\hline $\begin{array}{c}\text { Diabetic }+ \text { MSCs }+ \text { NIC } \\
\% \text { change } \\
\% \text { change } *^{2}\end{array}$ & $\begin{array}{c}0.18 \pm 0.002^{\mathbf{d}} \\
0 \\
-30.77 \\
\end{array}$ & $\begin{array}{c}0.38 \pm 0.004^{\mathbf{b}} \\
-33.33 \\
31.03 \\
\end{array}$ & $\begin{array}{c}4.50 \pm 0.03^{\mathbf{b}} \\
-17.13 \\
67.29 \\
\end{array}$ & $\begin{array}{c}7.26 \pm 0.04^{\mathbf{b}} \\
-6.2 \\
62.05 \\
\end{array}$ \\
\hline LSD & 0.008 & 0.0057 & 0.084 & 0.09 \\
\hline
\end{tabular}

$\mathrm{P} \leq 0.05$ there are no significant difference between means have the same letters in the same column.

$\%$ change: percentage change from normal control. $\%$ change*: percentage change from diabetic. 
Ropertson (2004) agreed with our results as he reported that persistent hyperglycemia during diabetes showed increased production of free radicals especially ROS which was reflected in increasing MDA and decreasing TOC, GPX and SOD levels in diabetic groups compared to normal control group.

The treatment with NIC had a protective effect on oxidative stress and antioxidant parameters which appeared clear in our results as there is a significant increase in serum TOC, liver GPX and SOD activities by $6.90 \%, 16.00 \%$ and $34.15 \%$, respectively in NIC group compared to diabetic group.

Oxidative stress can lead to the opening of mitochondrial membrane and lead to a significant loss of mitochondrial $\mathrm{NAD}^{+}$stores and subsequent cell injury, NIC maintain mitochondrial membrane potential and may protect cells from oxidative stress due to NIC-driven supply of $\mathrm{NAD}^{+}$and energy and these may be the reason of the improving effect of NIC on antioxidant parameters. The action of MSCs injection to restore the altered antioxidant enzymes in diabetic rats may indicate its free radical scavenging potential.

The results of Ibrahim and Rizk (2008) also go hand in hand with our results as they demonstrated that STZ-induced diabetes $(50 \mathrm{mg} / \mathrm{Kg})$ significantly suppresses the measured antioxidant systems including brain GPX and SOD activities and significantly elevated brain MDA. Treatment of diabetic rats with NIC could improve all the studied antioxidant systems including MDA, GPX and SOD. Also it was reported that in neurons exposed to high glucose, NIC reduces superoxide and hydrogen peroxide production and counteracts glucose-mediated cell death.

Additionally Kang et al. (2006) concluded that much lower levels of reactive oxygen species (ROS) accumulated in cells cultured in the presence of NIC; this suggested that NIC lowers ROS production or accelerates ROS removal during cell proliferation. NIC enhances an adaptive response to physical and chemical damage, which protects brain cells from oxidative damage and prevents injury of pancreatic islet cells during free radical exposure; protection of cells from oxidative stress during reperfusion is believed to be attributed to the NIC-driven supply of NAD ${ }^{+}$and energy. These results demonstrated that the duration and timing of NIC treatment affect the extent of prolongation of cellular lifespan. Therefore, NIC has a ROS-lowering effect in long-term culture.

In our study the treatment with MSCs had improving effect which is reflected in the significant decrease of serum MDA level by $19.23 \%$ while serum TOC and liver (GPX and SOD) activities were significantly increased in MSCs group by $13.80 \%$, $39.03 \%$ and $40.00 \%$, respectively compared to diabetic group.

Also the treatment with both of NIC and MSCs for 4 weeks is highly reflected in the improvement in MDA level with reduction by $30.77 \%$ compared to diabetic group and the elevation of the antioxidant enzymes activity of serum TOC, liver GPX and SOD by $31.03 \%, 67.29 \%$, and $62.05 \%$, respectively. 
Administration of MSCs $1 \times 10^{6}$ cells per rat significantly supported the influence of antioxidative system. It decreased MDA and concomitantly increased the activities of SOD and GPX in testes tissue. These results clearly demonstrate the anti peroxidative role of the MSCs. The in vivo protection by MSCs against oxidative damage may be refereed to its free radical scavenging potential (Hassan and Alam, 2014).

Additionally, Burova et al. (2013) reported that the specific responses of mesenchymal stem cells to oxidative stress may play a crucial role in regulation of tissue homeostasis as well as regeneration of organs after oxidative injury. It could also be due to direct scavenging /neutralization of the free radicals or induction of the endogenous antioxidant enzymes such as SOD.

High amounts of peroxides indicate either considerable production of prooxidative substances by the organism or impaired uptake or consumption of antioxidant by the organism. TOC test measure total lipid peroxides. Because of a direct correlation between oxygen radicals and lipid peroxidation it is possible to measure and characterize the oxidative stress in biological fluids (Reichenbach, 2002).

\subsection{Serum TC, TAGs, VLDL-C, HDL-C and LDL-C:}

Compared to normal control group, diabetic group showed a significant $(\mathrm{P} \leq 0.05)$ increase in TC, TAGs, VLDL-C and LDL-C levels while there was a significant decrease $(\mathrm{P} \leq 0.05)$ in HDL-C level as shown in table 3.

Diabetes mellitus affect virtually every lipids and lipoproteins and therefore, dyslipidemia is present in most diabetic patients. Dyslipidemia is reflected by elevated levels of triacylglycerols, VLDL-cholesterol and LDL-cholesterol and lower HDLcholesterol levels (Howard et al., 2003).

Serum lipid profile of rats were evaluated in a study performed by Pierre et al. (2012) and as expected, untreated diabetic rats showed a significant increase in serum TC, LDL-C and TAGs concentrations against low level of HDL-C. This increase in serum lipids is mainly due to increased fatty acid mobilization from adipose tissue, insulin deficiency or insulin resistance may be also responsible for hyperlipidemia.

The effective role of nicotinamide for treatment of diabetic rats was observed in diabetic + NIC and diabetic + MSCs + NIC groups, as they manifested a significant decrease in TC, TAGs, VLDL-C and LDL-C levels compared to diabetic group $(7.41 \%$, $5.13 \%, 5.14 \%$ and $10.50 \%$ ), respectively in the first group and by $21.19 \%, 25.30 \%$, $25.28 \%$ and $27.06 \%$, respectively in the second group. On the other hand HDL-C manifested a significant increase compared to diabetic group by $5.06 \%$ and $10.64 \%$, respectively.

Our results showed that MSCs have a significant reducing effect on serum lipid profile as TC level was reduced from $86.59 \pm 1.19 \mathrm{mg} / \mathrm{dl}$ in diabetic group to $76.58 \pm$ $0.78 \mathrm{mg} / \mathrm{dl}$ in MSCs group, TAGs level from $108.02 \pm 0.75 \mathrm{mg} / \mathrm{dl}$ to $95.45 \pm 0.65$ $\mathrm{mg} / \mathrm{dl}$, VLDL-C from $21.60 \pm 0.15 \mathrm{mg} / \mathrm{dl}$ to $19.09 \pm 0.13 \mathrm{mg} / \mathrm{dl}$, LDL-C from $51.04 \pm$ $1.20 \mathrm{mg} / \mathrm{dl}$ to $43.38 \pm 0.64 \mathrm{mg} / \mathrm{dl}$. HDL-C significantly increased from $13.44 \pm 0.26$ $\mathrm{mg} / \mathrm{dl}$ in diabetic group to $15.45 \pm 0.29 \mathrm{mg} / \mathrm{dl}$ in MSCs group. 
Table (3): Serum total cholesterol (TC), triacylglycerols (TAGs), very low density lipoprotein-cholesterol (VLDLC), high density lipoprotein-cholesterol (HDL-C) and low density lipoprotein-cholesterol (LDL-C) in diabetic rats treated with nicotinamide, mesenchymal stem cells or combination of them (mean $\pm \mathbf{S E}), \mathrm{n}=10$ rats.

\begin{tabular}{|c|c|c|c|c|c|}
\hline $\begin{array}{l}\text { Parameters } \\
\text { Groups }\end{array}$ & TC (mg/dl) & TAGs (mg/dl) & $\begin{array}{l}\text { VLDL-C } \\
(\mathrm{mg} / \mathrm{dl})\end{array}$ & $\begin{array}{l}\text { HDL-C } \\
(\mathrm{mg} / \mathrm{dl})\end{array}$ & $\begin{array}{l}\text { LDL-C } \\
\text { (mg/dl) }\end{array}$ \\
\hline Normal control & $55.68 \pm 0.31^{\mathbf{e}}$ & $62.21 \pm 0.36^{\mathbf{e}}$ & $12.44 \pm 0.07^{\mathrm{e}}$ & $15.43 \pm 0.26^{\mathrm{a}}$ & $27.88 \pm 0.25^{\mathrm{e}}$ \\
\hline Diabetic & $86.59 \pm 1.19^{\mathrm{a}}$ & $108.02 \pm 0.75^{\mathrm{a}}$ & $21.60 \pm 0.15^{\mathrm{a}}$ & $13.44 \pm 0.26^{\mathbf{c}}$ & $51.04 \pm 1.20^{\mathrm{a}}$ \\
\hline$\%$ change & 55.51 & 73.64 & 73.63 & -12.9 & 83.07 \\
\hline Diabetic + NIC & $80.17 \pm 0.52^{b}$ & $102.48 \pm 0.62^{\mathbf{b}}$ & $20.49 \pm 0.12^{b}$ & $14.12 \pm 0.25^{b c}$ & $45.68 \pm 0.75^{\mathbf{b}}$ \\
\hline$\%$ change & 43.98 & 64.73 & 64.71 & -8.49 & 63.85 \\
\hline$\%$ change* & -7.41 & -5.13 & -5.14 & 5.06 & -10.5 \\
\hline Diabetic+MSCs & $76.58 \pm 0.78^{\mathrm{c}}$ & $95.45 \pm 0.65^{\mathrm{c}}$ & $19.09 \pm 0.13^{\mathrm{c}}$ & $15.45 \pm 0.29^{\mathbf{b}}$ & $43.38 \pm 0.64^{c}$ \\
\hline$\%$ change & 37.54 & 53.43 & 53.46 & -6.35 & 55.6 \\
\hline$\%$ change* & -11.56 & -11.64 & -11.62 & 7.51 & -15 \\
\hline $\begin{array}{c}\text { Diabetic + MSCs } \\
\text { + NIC }\end{array}$ & $68.24 \pm 0.76^{\mathbf{d}}$ & $80.69 \pm 0.73^{d}$ & $16.14 \pm 0.15^{d}$ & $14.87 \pm 0.26^{\mathbf{a b}}$ & $37.23 \pm 0.72^{d}$ \\
\hline$\%$ change & 22.56 & 29.71 & 29.74 & -3.63 & 33.54 \\
\hline$\%$ change* $^{*}$ & -21.19 & -25.3 & -25.28 & 10.64 & -27.06 \\
\hline LSD & 2.19 & 1.81 & 0.63 & 0.75 & 2.28 \\
\hline
\end{tabular}

$\mathrm{P} \leq 0.05$ there are no significant difference between means have the same letters in the same column.

$\%$ change: percentage change from normal control. \% change*: percentage change from diabetic.

We concluded that this reducing effect of MSCs in lipid profile is due to its reducing effect on blood glucose level as blood glucose, insulin and C-Peptide levels significantly improved and returned to nearly normal levels, lipid profile also improved and returned to normal levels in MSCs group.

Also El Far et al. (2012) reported that transplantation of MSCs can correct and reverse the imbalance between ROS and antioxidant defense in favor of antioxidant defense by restoring and augmenting its capacity as well as modulating lipid peroxidation.

In agreement with our results $\boldsymbol{E} \boldsymbol{L}$-Sharkawy et al. (2013) reported that, although NIC lacks the hypolipidmic action of nicotinic acid, a trend toward increasing HDL-C (from 39.3 to $42.3 \mathrm{mg} / \mathrm{dl}$ ), and decreasing LDL (from 125.4 to $123.2 \mathrm{mg} / \mathrm{dl}$ ) and total cholesterol (from 249.5 to $234.5 \mathrm{mg} / \mathrm{dl}$ ) were reported in this study when hemodialysis patient started with NIC taken as $500 \mathrm{mg} /$ day and increased on day $8^{\text {th }}$ to $1000 \mathrm{mg} /$ day for eight weeks.

\subsection{Histological examination:}

Figures (1, 2, 3, 4 and 5) show the microscopic examination of pancreatic tissues. It is clear that pancreatic cells of diabetic rat's showed extensive damage and loss of architecture with marked atrophy of the islets of Langerhans accompanied by reduction in the number and size of $\beta$-cells. The islets of Langerhans showed necrosis, pyknosis (absence of nuclei) or hyperchromatic nuclei with cytoplasmic vaculation. 
The diabetic group showed varying degree of damage. Regular arrangement of islets has disturbed with atrophied islets appearance, vascular congestion as well as infiltration (Gopal et al., 2013). In diabetic control rats, pancreas sections showed severe congestion of pancreatic parenchyma and hyperplasia of cells (Rajasekar et al., 2014). Also histological examination of pancreatic sections revealed degenerated and necrotic cells in diabetic rats (Mahmoud et al., 2014).

Alenzi (2009) reported that the histological examination of diabetic rats in nicotinamide group $(1 \mathrm{~g} / \mathrm{kg} /$ day $)$ for 17 days showed no pathological changes and $\beta$ cells appeared normal. Histological analysis revealed a significant preservation of the percentage of the insulin-positive area within islets and of the amount of insulin extractable from total pancreas in diabetic rats treated with $500 \mathrm{mg} / \mathrm{kg}$ received $6 \mathrm{~h}$ prior to STZ injection (Kolb and Burkart, 1999).

Our results go hand in hand with Khaled et al. (2012), they reported that after treatment of diabetic rats by differentiated MSCs through a tail vain the islets showed substantial recovery. The islets of Langerhans were distinctly increased in size, the severity of degenerative and necrotic changes in the islet cells of Langerhans were less than those in the diabetic group with less acidophilic cytoplasm.

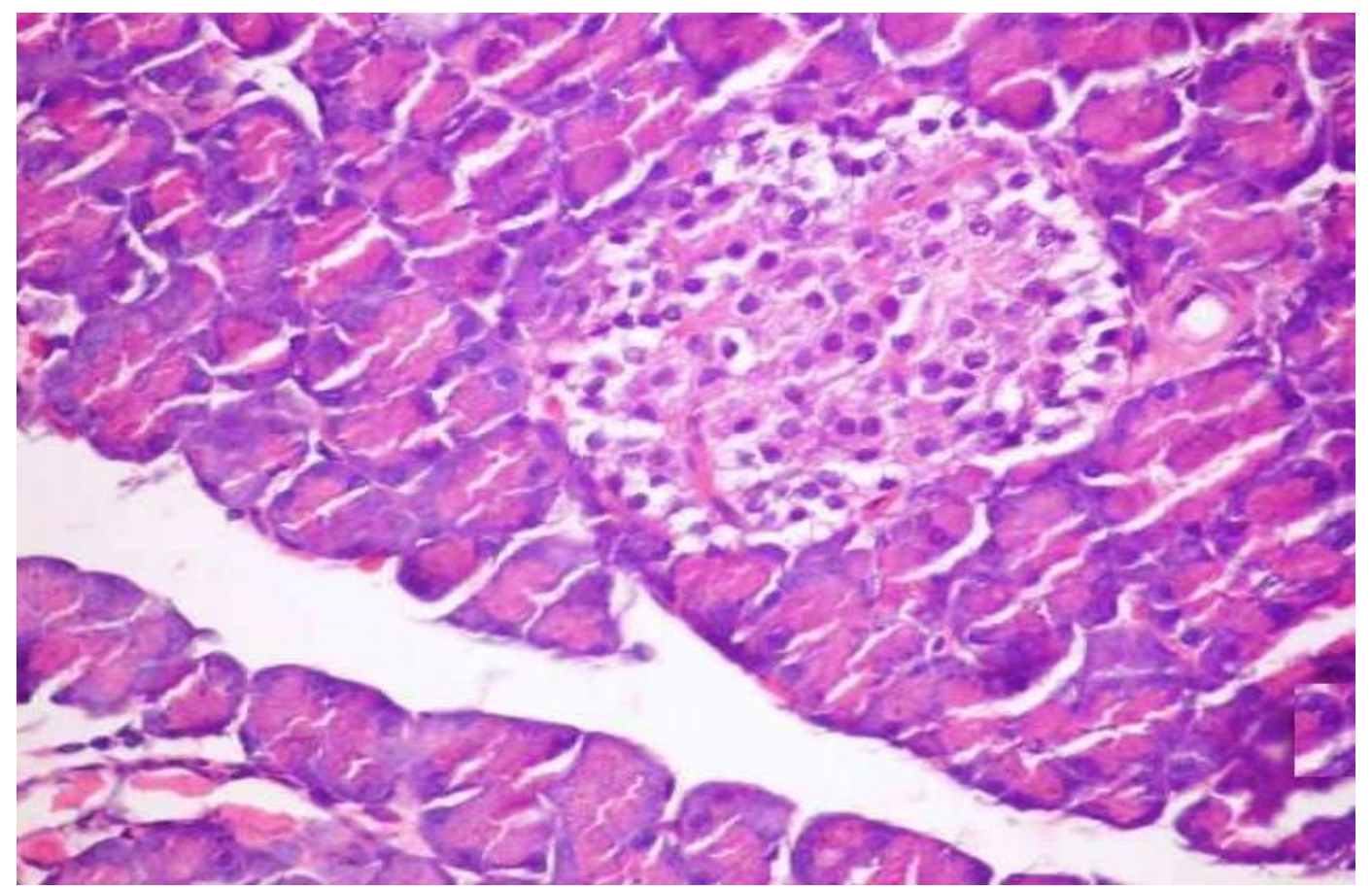

Fig. (1): Pancreas of normal rats (G1) showing normal appearance with normal $\beta$ - cells of Langerhans ( $H$ and $E \times 400)$. 


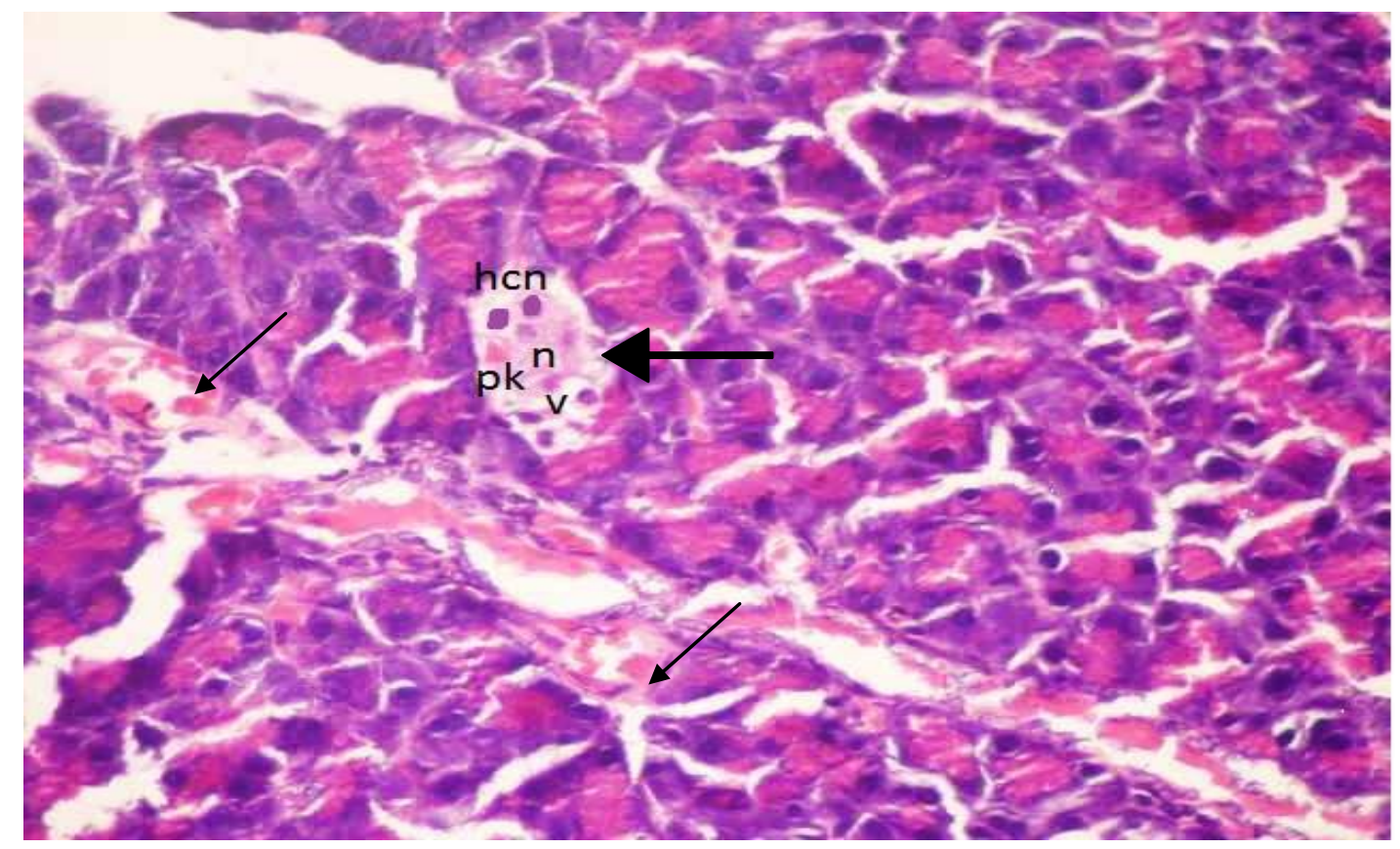

Fig. (2): Pancreas of diabetic rats (G2) showing: atrophy of islets of Langerhans (the large arrow) with necrotic cells (n), pyknotic nuclei (pk), vaculation (v), hyperchromatic nuclei (hen) and congested blood capillaries (the small arrow) $(\mathrm{H}$ and $\mathrm{E} \times \mathbf{4 0 0})$.

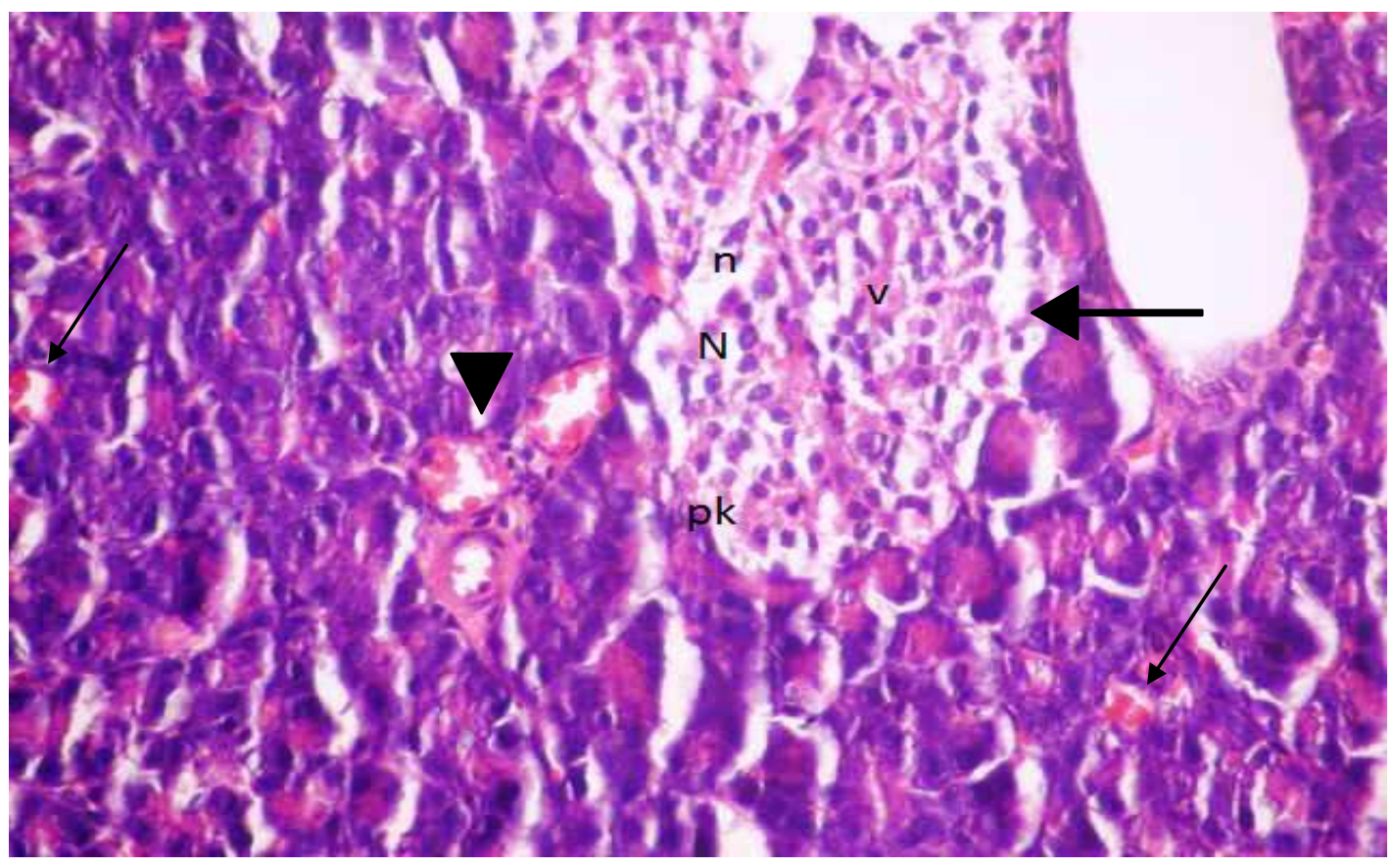

Fig. (3): Pancreas of diabetic rats treated with NIC (G3) showing: necrosis of islets of Langerhans (the large arrow), there are some normal cells $(N)$ but there are still few $\mathrm{n}$, pk and $\mathrm{v}$ some congested blood capillaries (the small arrow) and normal blood capillaries (the head of arrow) $(H$ and $E \times 400)$. 


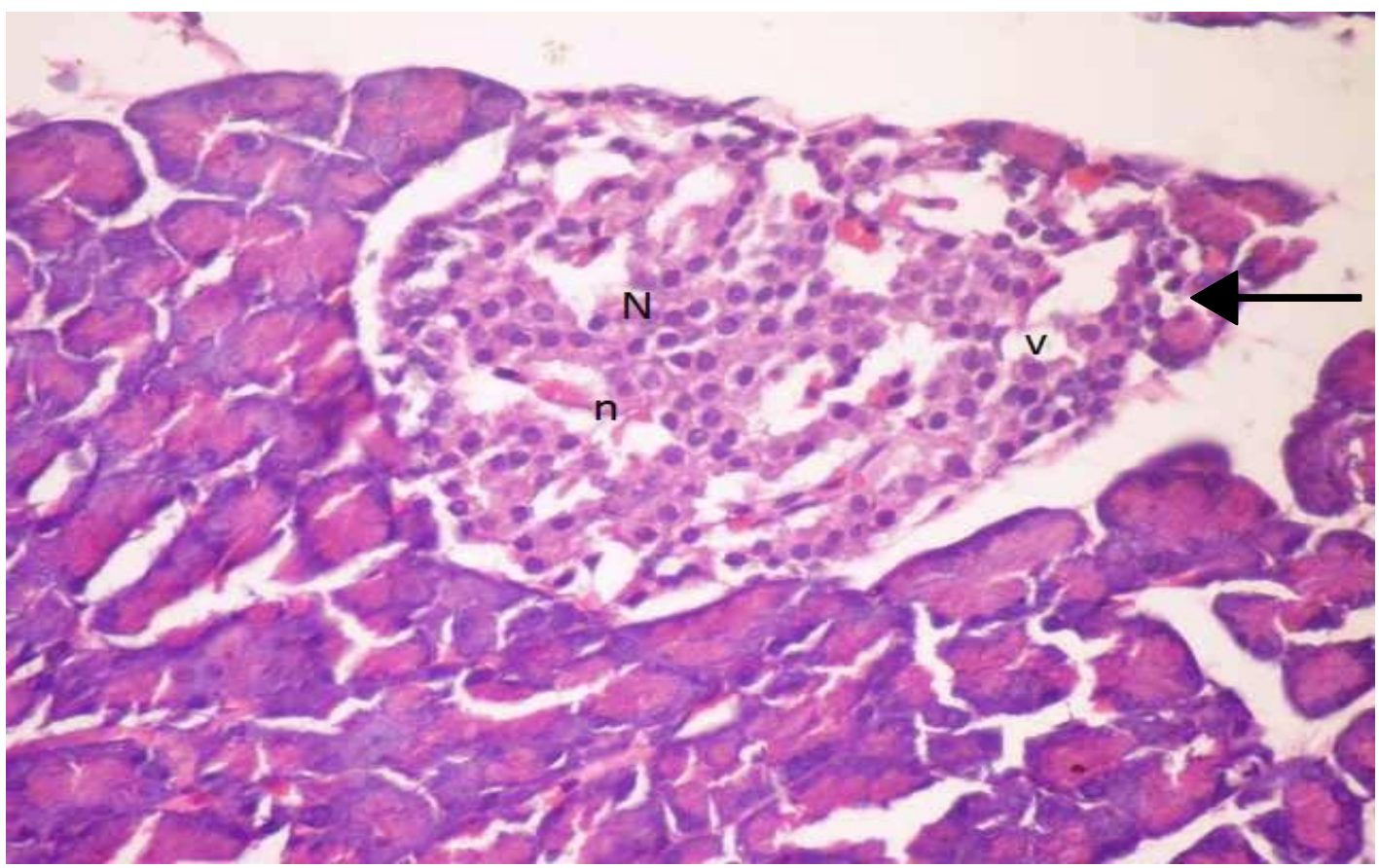

Fig. (4): Pancreas of diabetic rats treated with MSCs (G4) showing: slight increase in size of islets of Langerhans (the large arrow), most of the cells in the islets appear normal $(N)$ but there are still some $n$ and $v(H$ and $E \times 400)$.

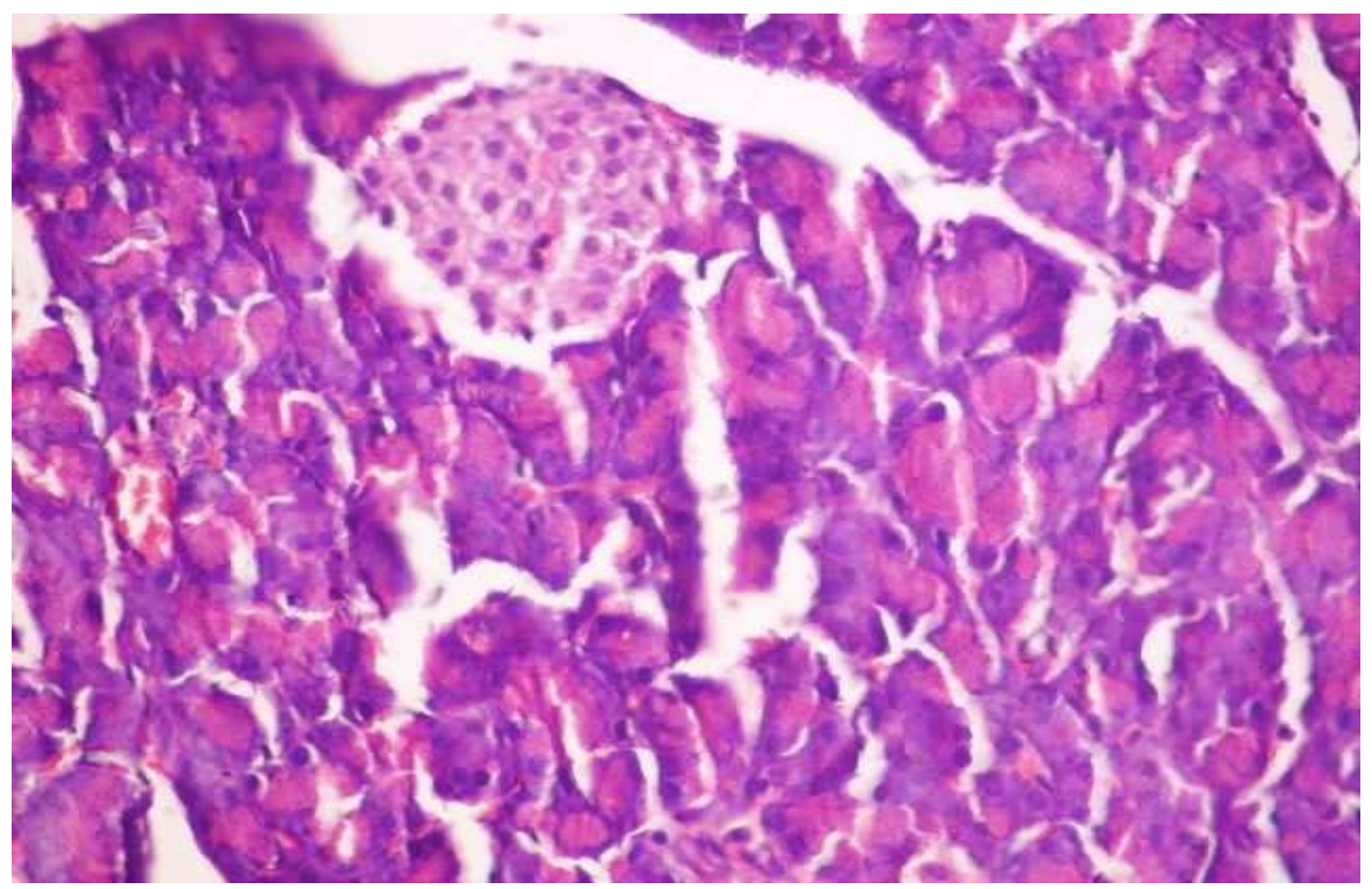

Fig. (5): Pancreas of diabetic rats treated with MSCs and NIC the islets showing no necrosis, atrophy or hyperplasia and most of cells appear normal and $\beta$-cells in the core of islets with improved integrity $(\mathrm{H}$ and $\mathrm{E} \times 400)$. 


\section{Conclusion}

Our study concluded that supplementation with nicotinamide may be useful during the treatment of diabetic rats with mesenchymal stem cells as it enhances proliferation of MSCs in media, slightly protect pancreas from damage and ameliorating the complications of diabetes.

\section{Acknowledgment}

Deep thanks were offered to Prof. Dr. Kawkab A. Ahmed, professor of pathology, Veterinary Medicine Faculty, Cairo University for her faithful help in the histopathological examination.

\section{References:}

Abdel Aziz M.T., El-Asmar M.F., Haidara M., Atta H.M., Roshdy N.K., Rashed L.A., Sabry D., Youssef M.A., Abdel Aziz A.T., Moustafa M., Effect of bone marrow-derived mesenchymal stem cells on cardiovascular complications in diabetic rats. Med. Sci. Monit.11, 429-455 (2008).

Alenzi F.Q. Effect of nicotinamide on experimental induced diabetes. Iran J. Asthma Immunol. 8(1), 11-18 (2009).

Allain C.C., Poon L.S., Chan C.S., Richmond W., Fu P.C., Enzymatic determination of serum total cholesterol. Clin. Chem. 20, 470-475 (1974).

Bancroft J.D., Gample M., Theory and practice of histological technique. $6^{\text {th }}$ ed, Churchill livingstone, Elsevier, China (2008).

Banerjee M., Kumar A., Bhonde R.R., Reversal of expermintal diabetes by multiple bone marrow transplantation. Biochem. Biophys. Res. Commun. 328(1), 318325 (2005).

Botsoglou N.A., Fletouris D.J., Papageorgiou G.E., Vassilopoulos V.N., Mantis A.J., Trakatellis A.G., Rapid, Sensitive, and Specific Thiobarbituric Acid Method for Measuring Lipid Peroxidation in Animal Tissue, Food and Feed stuff Samples. J. Agric. Food Chem. 42, 1931-1937 (1994).

Burova E., Borodkina A., Shatrova A., Nikolsky N., Sublethal oxidative stress induces the premature senescence of human mesenchymal stem cells derived from endometrium. Oxid. Med. Cell Longev. 474931. doi:10.1155 (2013).

Chen L., Jiang X., Yang L., Differentiation of rat marrow mesenchymal stem cells into pancreatic islet beta-cells. World J. Gastroenterol. 10(20), 3016-3020 (2004).

Dong Q., Chen L., Gao G., Wang L., Song J., Chen B., Xu Y., Sun L., Allogenic diabetic mesenchymal stem cells transplantation in streptozotocin-induced diabetic rats. Clin. Invest. Med. 31(6), 328-337 (2008).

El-Far M.A., Gabr M.M., El-Halawani S.M., Ibrahim R.Y., Khater S.M., Refaie A.F. Ghoneim M.A. Novel evidence of restoring and augmenting antioxidant 
defense after treatment of diabetic rats using stem cells. Biochem. Res. 14(2), 2537 (2012).

El-Sharkawy M., El-Hamamsy M., Allam S., kamel M., Ramadan A., Low Dose Nicotinamide as an Adjunctive Therapy to Calcium Carbonate for Control of Hyperphosphatemia in Hemodialysis Patients. Egypt. J. Hosp. Med. 53, 752-762 (2013).

Finlay J. W., Dillard R. F., Appropriate calibration curve fitting in ligand binding assay. AAPS. J. 9 (2): E260-E267 (2007).

Flohe L., Gunzler W.A. Oxygen radicals in biological systems. Methods Enzymol. 105, 114-212 (1984).

Fossati P., Burghen G.A., Li H., Hudson M.M., Kun L.E., Serum triglycerides determined calorimetrically with an enzyme that produce hydrogen peroxide. Clin. Chem. 8, 2078 (1982).

Friedewald W.T., Levy R.I., Fredrickson D.S., Estimation of concentration of LDL cholesterol in plasma without using preparative ultracentrifuge. Clin. Chem. Acta. 18, 499-842 (1972).

Gopal V., Mondal V., Mondal S.C., Biochemical investigation of standardized wattakaka volubilis leaf petroleum ether cold macerated extract against experimentally induced diabetes in rats. Pharmacologia 4(5), 391-399 (2013).

Guo C.H., Huag C.T., Chiou X.I., Hsu G.S.W., Alteration of trace elements distribution and testis ACE activity in mice with high peritoneal aluminum. Biol. Trace Elem. 85, 145-157 (2002).

Goldenberg R., Punthakee Z., Definition, Classification and Diagnosis of Diabetes, Prediabetesand Metabolic Syndrome, Can. J. Diabetes 37, S8-S11 (2013).

Hara N., Yamada K., Shibata T., Osago H., Hashimoto T., Tsuchiya M., Elevation of cellular NAD levels by nicotinic acid and involvement of nicotinic acid phosphoribosyl transferase in human cells. J. Biol. Chem.69, 618-628 (2007).

Hassan A.I., Alam S.S., Evaluation of mesenchymal stem cells in treatment of infertility in male rats. Stem cell research \& therapy 5, 131-137 (2014).

Howard B.V., Ruotolo G., Robbins D.C., Obesity and dyslipidemia. Endocrinol. Metab. Clin. 32(4), 855-867 (2003).

Ibrahim S.S., Rizk S.M., Nicotinamide: a cytoprotectant against streptozotocin induced diabetic damage in wistar rat brains. Afr. J. Biochem. Res. 2(8), 174180 (2008).

Kang H.T., Lee H.I., Hwang E.S. Nicotinamide exerts replicative lifespan of human cells. Aging Cell 5, 423-436 (2006).

Khaled M.A., El-belbesi H.I., Mahmoud M.F., Balah A.M., Molecular and Biochemical Studies on Stem Cells in Relation to Diabetes Mellitus. J. Americ. Sci. 8(7), 413-420 (2012). 
Kolb H., Burkart V., Nicotinamide in type 1 diabetes. Mechanism of action revisited Diabetes Care. Suppl 2, B16-20 (1999).

Krishna D., Rao S., Satyanarayana M.L., Serum insulin levels and lipid profiles of streptozotocin induced diabetic rats, J. Ind. Vet. Assoc. Kerala. (JIVA) 10(2), 22-27 (2012).

Kuchmerovska T., Shymanskyy I., Donchenko G., Pakirbaieva L., Kuchmerovskyy M., Klimenko A., Poly-ADP-ribosylation enhancement in brain cells nuclei is associated with diabetic neuropathy. J. Diabetes and Its Compl. 18(4), 198-204 (2004).

Kuchmerovska T., Shyanskyy I., Bondarenko L., Kilmenko A., Effects of nicotinamide supplementation on liver and serum contents of amino acids in diabetic rats. Eur. Med. Res. 13, 275-280 (2008).

Mahmoud A.M., Germoush M,O., Elgebaly H.A., Elsayed K.N.M., Hassan S., Mousa N.M., Hussein O.E., Anti-diabetic and insulin sensitizing effects of Padina Pavonia and Turbenaria Ornata in streptozotocin/nicotinamide diabetic rats. Asian J. Pharm. Clin. Res. 7(4), 74-78 (2014).

Mohan Y., Jesuthankaraj G. N., Thangavelu N. R., Antidiabetic and Antioxidant Properties of Triticumaestivum in Streptozotocin-Induced Diabetic Rats. Adv. Pharmacol. Sci. doi: 10.1155/2013/716073 (2013).

Oyanagi Y. Evaluation of assay methods and establishments of kit for superoxide dismutase. Anal. Biochem. 142, 290-296 (1984).

Pierre W., Gildas A.J.H., Ulrich M.C., Modeste W., Benoît N. T., Albert K., hypoglycemic and hypolipidemic effects of Bersamaengleriana leaves in nicotinamide/streptozotocin-induced type 2 diabetic rats. BMC Complement. Altern. Med. 12(264), 1-6 (2012).

Raja A.B., Elanchezhiyan C., Sethupathy S., Antihyperlipidemic activities of Helicteresisora fruit extract on streptozotocin induce diabetic male wistar rats. Eur. Rev. Med. Pharmacol. Sci. 14, 191-196 (2010).

Rajasekar R., Manokaran K., Rajasekaran N., Duraisamy G., Kanakasabapathi D., Effect of Alpinia calcarata on glucose uptake in diabetic rats-an in vitro and in vivo model J. Diabetes Metab. Disord. 13(1):33 (2014).

Ramiya V.K., Maraist M., Arfors K.E., Schatz D.A., Peck A.B., Cornelius J.G., Reversal of insulin-dependent diabetes using islets generated in vitro from pancreatic stem cells. Nat. Med. 6(3), 278-282 (2000).

Reichenbach $\mathbf{L}$. The politics of priority setting for reproductive health: breast and cervical cancer in Ghana. Repord Health Matters 10(20), 47-58 (2002).

Reves P.G., Nielsen F.H., Fahey G.C., AIN-93 purified diets for laboratory rodents: final report for the American Institute of Nutrition ad hoc writing committee on the reformulation of the AIN-76A rodent diet. J. Nutr. 123(11), 1939-1951 (1993).

Roperston R.B. Islet transplantation as a treatment for diabetes- a work in progress. N. Engl. J. Med. 350, 694-705 (2004). 
Shapiro A.M., Lakcy J.R., Ryan E.A., Korbutt G.S., Toth E., Warnock G.L., Kneteman N.M., Rajotte R.V.N., Islet transplantation in seven patients with type 1 diabetes mellitus using a glucocorticoid-free immunosuppressive regimen., Engl. Med. 343, 230-238 (2000).

Steel R.G.D., Torrie J.H., Principles and procedures of statistics, $2^{\text {nd }}$ ed. New York, McGraw-Hill (1980).

Surjana D., Halliday G.M., Damian L.D. Role of nicotinamide in DNA damage, Mutagenesis and DNA repair. J. Nucleic Acids 10, 1-13 (2010).

Thorell J. I., Lanner, A., Influence of Heparin-Plasma, EDTA-Plasma and Serum on the determination of insulin with three different radioimmunoassays. Scand. J. Clin. Lab. Invest. 31, 187-190 (1973).

Tsai P., Wang H., Shyr Y., Weng Z., Tai L., Shyu J., Chen T., Transplantation of insulin-producing cells from umbilical cord mesenchymal stem cells for the treatment of streptozotocin-induced diabetic rat, J. Biomed. Sci. 19 (47), 1-9 (2012).

Ursini F., Maiorino M. Gregolin C. The selenoenzyme phospholipids hydroperoxide glutathione peroxidase. Biochim. Biophys. Acta. 839: 62-70 (1985).

Urbán V.S., Kiss J., Kovács J., Gócza E., Vas V., Monostori E., Uher F., Mesenchymal stem cells cooperate with bone marrow cells in therapy of diabetes. Stem Cells 26, 244-253. J. Biomed. Sci. 19(47), 1-9 (2008).

Wang H.S., Shyu J.F., Shen W.S., Hsu H.C., Chi T.C., Chen C.P., Huang S.W., Shvr Y.M., Tang K.T., Chen T.H., Transplantation of insulin producing cells derived from umbilical cord stormal mesenchymal stem cells to treat NOD mice. Cell Transplant. 20(3), 455-466 (2011). 


\title{
تعاون النيكوتيناميد مع الخلايا الجذعية الوسيطة للتحكم في مرض السكر المحدث عن طريق التوذيق الاستربتوزوتوسين في الجرذان
}

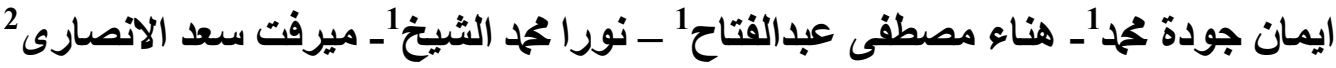

\author{
1 قسم الكيمياء الحيوية و التغذيةـ كلية البنات للآداب و العلوم و التربية ـجامعة عين شمس ـ القاهرة ـمصر \\ 2 قسم الباتولوجى- كلية الطب- جامعة القاهرة

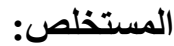

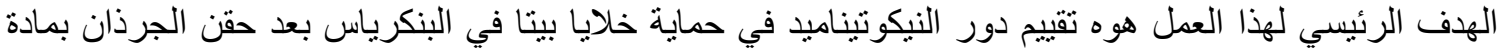

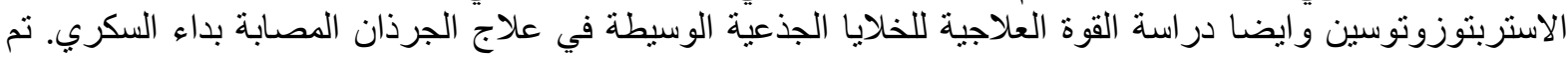

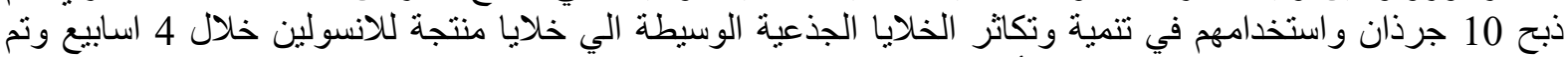

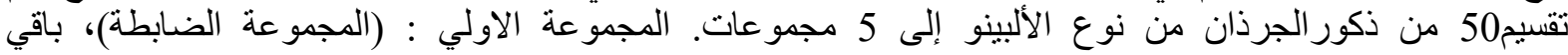

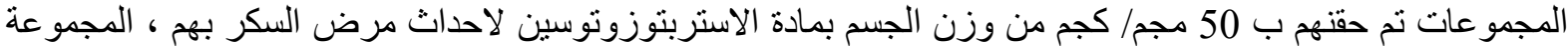

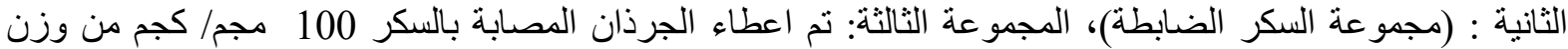

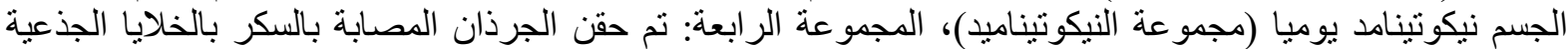

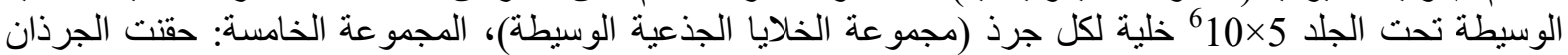

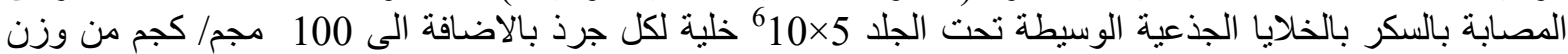

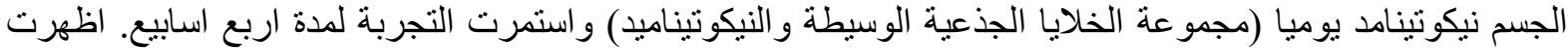

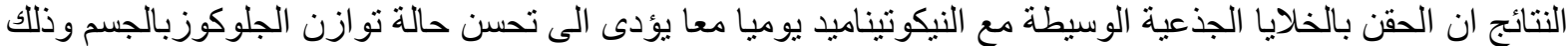

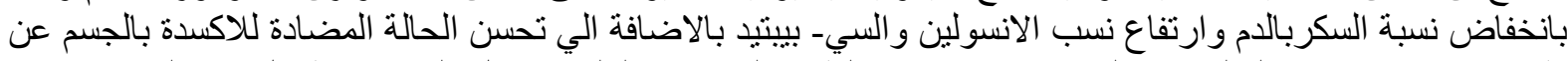

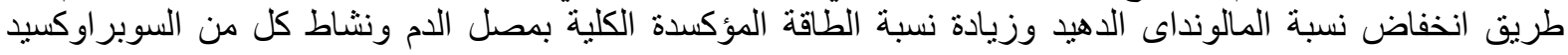

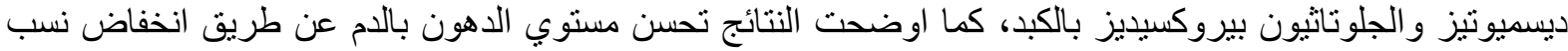

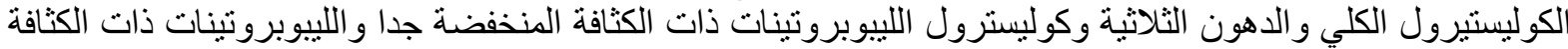

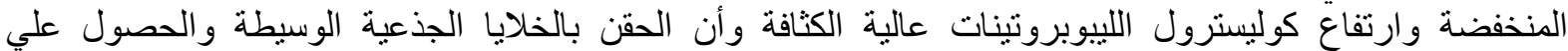

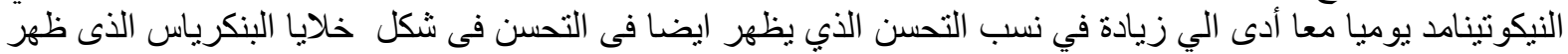
من خلال فحص الانسجة.

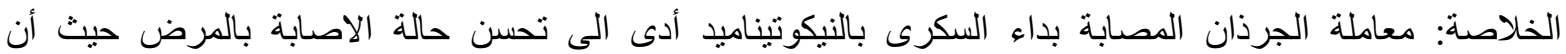

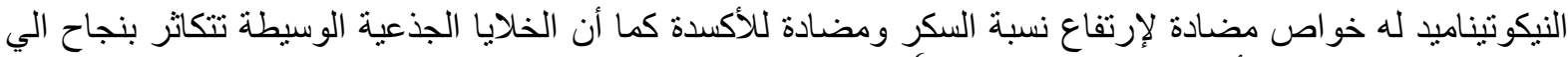

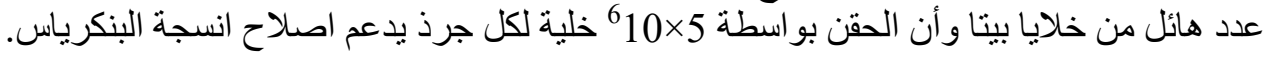

الكلمات المفتاحية: الخلايا الجذعية الوسيطة، الاصدابة بمرض السكر عن طريق الاستربتوزوتوسين، النيكوتيناميد،

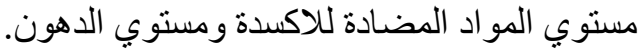

